\title{
Influencing Factors of Vocational High School Revitalization Policy Implementation
}

\author{
Delfiazi Puji Lestari* \\ Public Administration, Faculty of Social and Political \\ Universitas Diponegoro \\ Semarang, Indonesia \\ *fiazuhdi@gmail.com
}

\author{
Endang Larasati, Sundarso, Ida Hayu Dwimawanti \\ Faculty of Social and Political Science \\ Universitas Diponegoro \\ Semarang, Indonesia
}

\begin{abstract}
Presidential Instruction No.9 2016 was issued by the government with the aim of improving the quality of vocational high school graduates in Indonesia. However, in its implementation there are still many problems. Studies on the problems of revitalizing vocational education was seen and researched by several authors around the world with several theories. This study conducted differently from previous research by using implementation theory in revitalization policy analysis referred to Van Meter and Van Horn Implementation theory. The purpose of this study was to analyze how was the implementation of revitalization policy of vocational high school as well to identify what influence factors were obstacles or supporters in the implementation of revitalization policy in Sumatera Selatan province. This descriptive qualitative research used primary data collection techniques by observation and interviews. Also, documentation the secondary data. The data analysis technique uses Spiral Model by Creswell and Triangulation and Rich Thick Description as a data validity technique. The results showed that responses from the provincial government could be said to be late. Improvement in human resources was still needed. Communication between organizations, both government or business and industry, had not been carried out properly. Fragmentation and sectoral ego at the bureaucracy. Meanwhile support from the community was quite good for this program. Recommendations that could be given were collaborating with related organizations.
\end{abstract}

Keywords-implementation, revitalization, policy, vocational high school

\section{INTRODUCTION}

According to the mandate of National Education System Law, article 152003 vocational high school (VHS) graduates are prepared to fill job vacancies in world industrialized business. So that policy of revitalization policy was issued by Presidential instruction number 9 of 2016.

There are many problems occurred related to the implementation of this VHS revitalization policy, especially in South Sumatra province. This province is one of the largest provinces of Sumatra Island with a population economy in the agricultural sector. Two of the 4 State VHS that received policy revitalization in South Sumatra province are those with priority areas of expertise namely State VHS number 1 Gelumbang with agricultural expertise: and State VHS number 6 Palembang with the field of tourism expertise. Meanwhile State Vocational High School number 1 Lahat and State Vocational High School number 3 Palembang with technical expertise.

Previous research used several theories, namely Stephen's six main principles [1]. The Basic Entrepreneurship Skills for Self-Employment [2], Five Strategies in Revitalization [3], Leadership Theory [4], Administrator Theory [5], Realistic Evaluation Framework with a Total Quality Management (TQM) Framework [6], Theory of Development [7] and the Model of Employee Partnership. Meanwhile this research conducted differently from previous research by using implementation theory in revitalization policy analysis. The implementation theory referred to the Van Meter and Van Horn Implementation theory.

In general, all the supporting and inhibiting factors for implementation by many experts has variable equations. The differences were just the way of expressing it. Some of these variables had accommodated by the variables in Van Meter Van Horn implementation model. The purpose of this study was to analyze the influencing factors of the implementation of the revitalization policy at the south Sumatra province.

\section{MEthodology}

This type of research is qualitative research, i.e., research which was used to test the condition of the object where the researcher was key instrument. Based on the type of data and analysis, this research was descriptive qualitative, aiming to describe and analyze influencing factors of implementation of vocational high school revitalization policy namely:

- policy standards and objective

- policy resources

- interorganizational communication

- disposition

- characteristics of the agencies 


\section{- social, economic, and political environment}

Research sites were states VHS number 1 Gelumbang as the first agricultural vocational school in South Sumatra province, and state VHS number 6 Palembang as the first vocational school in Palembang with a tourism expertise. The Informant determination technique used Purposive method to find out the key informants, and the snowball method.

Data collection techniques uses interview, observation, and documentation. Interview was conducted with the purpose of data collection complete, in-depth, and accurate so that helped researchers to analyze the problems of research in a more incisive about the process of implementation of the vocational high school revitalization policy. Observation was done with regards to implementation of vocational high school revitalization policy. Documentation by Analyzing the books or literature relating to research especially, documentation, as well as journals relating to the influencing factors of the implementation vocational high school revitalization policy. The data validation techniques used in this study were triangulation by matching data or ensuring the correctness of the data from informants to other informants; and Rich Thick Description by make a detailed, clear, systematic, and reliable report that broke down.

The data analysis technique used was the Spiral Model by Creswell et al. [8]. The data were set, read, and made memos, then described and interpreted according to the focus of the research, namely Influencing Factors of Vocational High School Revitalization Policy Implementation. Then the research data was presented, and the discussion was carried out using the theory and concepts of educational policy and the Van Meter Van Horn policy implementation model. Furthermore, the authors packaged it in narrative form (text).

\section{RESULTS AND DISCUSSION}

\section{A. Policy Standards and Objective}

To strengthen efforts to improve the quality of VHS, the government issued a VHS revitalization policy (Presidential Instruction No. 9 of 2016). Ideally, a public policy issued by the central government should be accompanied by regulations or public policies at lower levels. In this case namely the governor's regulation. This governor regulation will be a guideline for policy implementers. But unfortunately, the supporting regulation just issued in October 2019, namely the governor regulation number 22-year 2019, this regulation was issued after 3 years of the Presidential Instruction in 2016. So far, the implementation of the revitalization policy has been carried out by referring to the revitalization serial books published by the central SMK sector. In fact, the technical authority to implement education policies at the senior secondary level rests with the provincial government. It indicates the slow response of local governments in responding to this revitalization policy.

On the other hand, according to Mazmanian and Sabatier [9], policy standards and objectives that are carefully formulated and clearly arranged in an order of importance play a very important role as an assisting instrument in evaluating programs, as concrete guidelines for implementing officials and as a source of support for the goal.

However, in general in Indonesia, only 5 provinces have issued supporting regulations in the form of governor regulations. The five provinces are DKI Jakarta, West Java, East Java, South Sumatra, and Bangka Belitung provinces.

The slow response from the governors was due to the nature of this Presidential Instruction which is only a direction from the president and is not obligatory. In contrast to Presidential regulations which applied to everyone in general and remain until the regulation is repealed or replaced by new regulations. Meanwhile, presidential instruction is only limited to provide direction, guidance, in the implementation of tasks [10].

\section{B. Policy Resources}

Human resources are all teachers, both productive and nonproductive teachers who have a role in this policy at a lower level as well as being a policy target. Based on the main data of VHS 2018 , there were 2640 productive teachers $(38.8 \%)$ and $4170(61.2 \%)$ Adaptive teachers. As for the level of education, in the province of South Sumatra, it could be seen that the highest percentage of teachers who have received professional certificates is at the special education level with 39.03 percent, followed by elementary school teachers with 38.87 percent, junior high school teacher 38.29 percent, high school teacher's 31.76 percent, while the lowest was at SMK level 21.83 percent.

According to Edward III in Indiahono [11] human resources are the adequacy of both the quality and quantity of implementers that can cover all target groups. Financial resources are the adequacy of investment capital for a program / policy.

Financial resources referred to in this policy are financial resources that have been budgeted by the central government for the smooth running of this revitalization policy. The time resource is the target of achievement that has been determined by the government, in this case the education office, which is compiled in the 5-year SMK roadmap. Availability of funds includes how much funds are allocated; and prediction of the strength of funds and the amount of costs for program / policy implementation [11].

\section{Interorganizational Communication}

Communication between implementing agencies refers to the procedural mechanisms that are launched to achieve program goals and objectives. Communication and coordination between agencies, both vertically and horizontally, has not been going well. Vertically, the communication between the education office and schools has been carried out in the form of socialization and assistance. Horizontally, the coordination carried out by the education office with the business world and the industrial world has not 
been carried out properly. So far socialization to the business world and industrial world is carried out by schools directly. Communication between agencies, for example the education office and the manpower and transmigration office, has not been implemented optimally. Each agency performs its own duties and functions. There was almost no coordination. Yet coordination is a powerful mechanism for implementing public policy. The sectoral ego between agencies was very pronounced. Bappeda has not yet carried out its duties and functions as coordinator between OPDs.

Meanwhile according to Hood [12] that to achieve perfect implementation, a single administrative unit system is needed to create good coordination. Communication and coordination have a very important role in the implementation process because the data, conditions and commands can be understood in accordance with what is desired.

Hood also mentioned that in most organizations that have departmentalization, professionalization characteristics, and various group activities that protect group values and interests, there is almost no perfect coordination. These two things, communication and coordination often do not get good attention in the implementation of an activity. Moreover, it must be perfect. And the existence of sectoral egos between related agencies that worsens the situation.

\section{Disposition}

At the provincial level, related agencies carried out their duties in accordance with the main duties and functions of each agency. So that the understanding of this policy as something that was integrated is still low, as a result they tended to refuse to implement this policy, because they felt they were not part of their main duties and functions.

At the implementing level, teachers, and education personnel as implementers in the field already knew about this policy, but most of them thought that this revitalization policy was only a grant which had an impact on the number of reports they had to make. So that adds to their work.

Winarno [13] identifies three elements of executive responses that may affect their ability and willingness to implement policies, namely: Cognition (comprehension, understanding) of policies; Kinds of response to it (acceptance, neutrality, and rejection) as well as the intensity of the response to the policy. Meanwhile According to Indiahono [11] the ability of human resource implementors can be seen from the level of education; the level of understanding of the goals and objectives and the application of program details; as well as the ability to deliver programs and direct.

\section{E. Characteristics of Agencies}

Bureaucratic structure is defined as the characteristics, norms and patterns of relationships that occur repeatedly in executive bodies that have a potential or real relationship with what they have by implementing policies.
In the Presidential Instruction No. 9/2016, it is stated that the presidential instruction is addressed to governors throughout Indonesia. In accordance with the existing bureaucratic structure, the regional secretariat has the authority to carry out this presidential instruction. The regional secretariat acts as the Team leader and Bappeda as the secretary. However, the Bappeda of South Sumatra was not carrying out its coordination function properly. So that each agency operated independently without any coordination and direction from the authorized agency.

It indicates the fragmentation in the bureaucratic. According to Edward, fragmentation is the spread of responsibility for a policy area among several organizational units. "Fragmentation is the dispersion of responsibility for a policy area among several organizational units." The more actors and agencies involved in a particular policy and the more interrelated their decisions are, the less likely it is that successful implementation will be. According to Edward also, in general, the more coordination is needed to implement a policy, the less chance it will be successful.

\section{F. Social, Economic and Political Environment}

The last thing that needs to be considered to assess the performance of public implementation in the perspective offered by Van Metter and Van Horn is the extent to which the external environment contributes to the success of the established public policies. The social, economic, and political environment that supports this policy includes the environment of entrepreneurs who want competent SMK graduates who can play an active role in improving their businesses. Politically, the SMK revitalization policy is one of the ideals carried out by the government of President Joko Widodo. Nawacita has placed vocational education as the top priority for education development.

When this policy was launched in 2016, there was no political support from the provincial government in the form of legislation. Regulations in the form of new Governor regulations were issued by the governor in the next period. The support from the new governor was also linear with the current governor's vision and mission, which was to reduce poverty to single digits. One of the instruments is to encourage SMK alumni to be absorbed as much as possible in business and industry. Support from professional organizations and community such as the Indonesian chef association and the Indonesian hotel association was also quite good.

Non-conducive social, economic, and political environments can be the culprit of failure of policy implementation performance.

\section{CONCLUSION}

This research field was study of public administration, especially public policy implementation. Previous research using various theories, meanwhile this study referred to Van Meter and Van Horn Implementation theory. 
The implementation of the revitalization policy in South Sumatra province had been running but was still partial. The government's response in issuing supporting legislation is due to the nature of the presidential instruction. Province Government was too late to issue a rule as a policy standard and objective of revitalization VHS. The executing actors, who should have assumed the role of coordinators, did not carry out their duties. Human resources, namely teachers and education personnel, still needed to be improved. Supports from the central government in the form of grants for the development of VHS in the provinces was a potential resource. Communication and coordination factors between organizations were still weak, both vertically and horizontally. The fragmentation in the bureaucratic was still exist. Support came from the provincial government in the form of supporting regulation and community.

To make the implementation of this revitalization policy run well in the future, collaboration between local government organizations must be carried out. It was necessary to form a solid team in implementing this policy. The business world and industry as well as academia must be involved in the process of implementing this policy.

\section{REFERENCES}

[1] M. Stephens, S. Fitzpatrick, M. Elsinga, G. Van Steen and Y. Chzhen, Study on housing exclusion: Welfare policies, housing provision and labour markets. European Commission/University of York, 2010.

[2] G.G. Akindanso, O. Promise and O. Beloved, "Revitalizing Technical, Vocational Education And Training Through Entrepreneurship
Education For Self Employment In Kogi State," Odumegwu Ojukwu Journal Of Vocational Education And Research, vol. 2, no. 1, pp. 2630708, 2017.

[3] J.I. Obidile and H.E. Uzoekwe, "Revitalization of the Technical and Vocational Education (TVE) Programmes for Youth Empowerment in Nigeria," International Journal of Vocational Education and Training Research, vol. 4, no. 1, pp. 45-47, 2018.

[4] M.E. Wonacott, Leadership development in career and technical education. ERIC Clearinghouse on Adult, Career, and Vocationa Education, Center on Education and Training for Employment, College of Education, the Ohio State University, 2001.

[5] C.R. Finch, Assessing Leadership Behavior: Beyond Task Analysis, 1989.

[6] R. Pawson and N. Tilley, "An introduction to scientific realist evaluation," Evaluation for the 21st century: A handbook, pp. 405-418, 1997.

[7] J. Sachs, J.W. McArthur, G. Schmidt-Traub, M. Kruk, C. Bahadur, M. Faye and G. McCord, "Ending Africa's poverty trap," Brookings papers on economic activity, vol. 1, pp. 117-240, 2004.

[8] J.W. Creswell, W.E. Hanson, V.L. Clark Plano and A. Morales, "Qualitative research designs: Selection and implementation," The counseling psychologist, vol. 35, no. 2, pp. 236-264, 2007.

[9] D.A. Mazmanian and P.A. Sabatier, "A multivariate model of public policy-making," American journal of political science, pp. 439-468, 1980.

[10] J. Asshiddiqie, Perihal Undang-Undang. Jakarta: Rajawali Pers, 2010.

[11] D. Indiahono, "Mengubah Netralitas Birokrasi Klasik Menjadi Netralitas Birokrasi Baru," Civil Service Journal, vol. 3, 2009.

[12] P. Hood, "Frontal solution program for unsymmetric matrices," International Journal for Numerical Methods in Engineering, vol. 10, no. 2, pp. 379-399, 1976

[13] B. Winarno, Kebijakan Publik, Teori Proses dan Studi Kasus, CAPS Jakarta, 2011 